\title{
Gastric Ulcer Etiology
}

\author{
Maria Izabel Gomes Silva and \\ Francisca Cléa Florenço de Sousa \\ Federal University of Ceará \\ Brazil
}

\section{Introduction}

A gastric ulcer, also called stomach ulcer, is a break in the normal gastric mucosa integrity that extends through the muscularis mucosa into the submucosa or deeper. The incidence varies with the age, gender, geographical location and is associated with severe complications including hemorrhages, perforations, gastrointestinal obstruction, and malignancy. Thus, this clinical condition represents a worldwide health problem because of its high morbidity, mortality and economic loss (Brown \& Wilson, 1999; Dimaline \& Varro, 2007).

The normal stomach mucosa maintains a balance between protective and aggressive factors. Some of the main aggressive factors are gastric acid, abnormal motility, pepsin, bile salts, use of alcohol and nonsteroidal anti-inflammatory drugs (NSAID), as well as infection with microorganisms (Helicobacter pylori and others). On the other hand, mucus secretion, bicarbonate production, gastroprotective prostaglandin synthesis and normal tissue microcirculation protect against ulcer formation. Although in most cases the etiology of ulcer is unknown yet, it is generally accepted that gastric ulcers are multifactorial and develop when aggressive factors (endogenous, exogenous and/or infectious agents) overcome mucosal defense mechanisms (Allen \& Garner, 1980; Wallace, 1992; Peskar \& Marici, 1998; Tulassay \& Herszényi, 2010).

In this context, the present chapter aims to address etiologies multiples of gastric ulcer development, clarifying how the imbalance between aggressive and defensive factors leads to this clinical condition. For this purpose, we review basic components of gastric mucosal defense and discuss conditions in which mucosal injury is directly related to impairment in mucosal defense.

\section{Gastric protective factors}

The stomach is lined by a complex epithelium that forms a selective barrier between the external environment (lumen) and the body, which is folded into several branching, tubular gastric glands that reach deep into the muscularis mucosa. The diverse range of functions performed by gastric epithelial cells is maintained in the face of a hostile luminal environment that can contain up to $150 \mathrm{~mm} \mathrm{HCl}$ and aggressive proteases, which are capable of digesting tissue, as well as a variety of noxious pathogens (Dimaline \&Varro, 2007). Despite continuous exposure to these injurious factors, under normal conditions a 
large number of defense mechanisms prevent local damage and maintain structural and functional mucosal integrity (Tulassay \& Herszényi, 2010).

In general, gastric defense mechanisms consist of a gastric mucosal "barrier". It is a multilayer system, which include a preepithelial mucus-bicarbonate "barrier", an epithelial "barrier" (surface epithelial cells connected by tight junctions), and a subepithelial component including blood flow and nerves. (Henriksnäs et al., 2006; Dimaline \& Varro, 2007; Nayeb-Hashemi \& Kaunitz, 2009).

\subsection{Gastric mucosal "barrier"}

\subsubsection{Preepithelial mucus-bicarbonate "barrier"}

The regular exposure of the stomach to endogenously produced acid and degrading enzymes requires the presence of an efficient gastric mucosal "barrier". Since the first experimental evidence for the mucus bicarbonate barrier was reported about three decades ago (Allen, 1978; Allen \& Garner, 1980), it has become firmly established as a key component of the gastroduodenal mucosal protective mechanisms against noxious agents (Allen \& Flemström, 2005). This barrier constitutes the first line of mucosal defense and is formed by mucus gel, bicarbonate ( $\mathrm{HCO}-$ ), and surfactant phospholipids, which cover the mucosal surface (Lichtenberger, 1999; Allen \& Flemström, 2005).

The gastric mucus consists of a viscous, elastic, adherent and transparent gel secreted by apical expulsion from surface epithelial cells. It is formed by $\sim 95 \%$ water and $\sim 5 \%$ mucin glycoproteins that covers the entire gastrointestinal mucosa, and its luminal surface is coated with a film of surfactant phospholipids with strong hydrophobic properties. The HCO3- is secreted by surface epithelial cells and its role is to neutralize acid diffusing into a stable, adherent mucus gel layer and to be quantitatively sufficient to maintain a nearneutral pH $(\sim 7.0)$ at the mucus-mucosal surface interface (Figure 1) (Hills et al., 1983; Lichtenberger 1999; Repetto \& Llesuy, 2002; Tulassay \& Herszényi, 2010).

In contrast to stomach acid, pepsin has received relatively little attention as the other endogenous aggressor in gastric juice. Pepsin damage is characterized by focal areas of discontinuity in the adherent mucus layer, localized hemorrhagic punctuate ulcers with bleeding into the lumen, and no evidence of reepithelialization or mucoid cap formation (Allen \& Flemström, 2005). Thus, the unstirred mucus gel layer is also a physical barrier to luminal pepsin accessing the underlying mucosa. It retains HCO3- secreted by surface epithelial cells, preventing penetration of pepsin and therefore proteolytic digestion of the surface epithelium (Tulassay \& Herszényi, 2010). Therefore, a dissipation of the mucus gel and phospholipid layer by ulcerogenic substances (such as aspirin and bile salts) leads to both acid back-diffusion and mucosal injury. (Darling et al., 2004; Allen \& Flemström , 2005). Moreover, if some oxygen radicals are generated in surface epithelium containing mucus, intracellular mucus could scavenge them, acting as an antioxidant and thus reducing mucosal damage mediated by oxygen free radicals. (Penissi \& Piezzi, 1999; Repetto \& Llesuy, 2002). Even when cells containing mucus are damaged by extracellular oxygen radicals, intracellular mucus may be released into the gastric tissue and prevent additional damage by scavenging them (Seno et al., 1995).

The efficacy of protective properties of the mucus barrier depends not only on the gel structure but also on the amount or thickness of the layer covering the mucosal surface (Penissi \& Piezzi, 1999; Repetto \& Llesuy, 2002). The thickness of this layer is the result of a dynamic balance between its secretion and its erosion mechanically by shear forces of the 
digestive process and by proteolytic degradation, particularly from luminal pepsin in stomach. Compared with other gastrointestinal secretions, the adherent mucus gel form is physically unique. Studies have shown that adherent mucus gels from stomach, duodenum, and colon are all well-defined viscoelastic gels that do not dissolve on dilution (Allen et al., 1976; Allen, 1989; Allen \& Flemström, 2005). They flow over a relatively long time (30-120 min), reannealing when sectioned. Thus, mucus gels are known stable substances, and exposure of isolated gastric mucus gel to $\mathrm{pH} 1-8$, hypertonic salt, or bile does not disperse or affect its rheological properties. In functional terms, these recognized properties contribute to the adherent mucus gel layer forming a continuous and effective protection over the mucosa (Allen \& Flemström, 2005)

The mucus bicarbonate barrier is the only preepithelial barrier between epithelium and lumen. When it is overwhelmed or breaks down in different disease conditions, the next series of protective mechanisms come into play, including epithelial repair, and maintenance and distribution of mucosal blood flow (Tulassay \& Herszényi, 2010).

\subsubsection{Epithelial "barrier"}

Subsequent to mucus-bicarbonate "barrier", the next line of mucosal protection is formed by a continuous layer of surface epithelial cells, which secrete mucus and bicarbonate and generate prostaglandins (PGs), heat shock proteins, trefoil factor family peptides (TFFs), and cathelicidins. This epithelial barrier serves to separate the digestive lumen from the internal compartments of the organism. Its main role is to maintain a selective exchange of different substances (secretions, nutrients, etc.) between these two compartments, and to assure the protection of the organism against the penetration of micro-organisms and other exogenous antigens, essentially contained in food. In this context, two crucial elements of the digestive epithelial barrier assure these functions: the epithelial cells and the intercellular junctions (tight junctions). Both structures provide two pathways for transepithelial transport: transcellular and paracellular routes, respectively (Figure 1). (Matysiak-Budnik, et al., 2003; Laine et al., 2008; Tulassay \& Herszényi, 2010). Because of the presence of phospholipids on epithelial cells surfaces, these cells are hydrophobic and therefore repel acid- and watersoluble damaging agents (Lichtenberger et al., 1983).

The paracellular pathway seems to be the major route of transepithelial macromolecular permeation. This route is a complex array of structures that are mainly controlled by tight junctions between epithelial cells, which appear to be key regulators of gastrointestinal permeability to macromolecules such as endotoxin and other bacterial products. Also, interconnected by tight junctions, the surface epithelial cells form a "barrier" preventing back diffusion of acid and pepsin (Farhadi et al., 2003; Werther, 2000; Laine et al., 2008). The physiology of this tightly regulated conduit is not fully known. However, this dynamic gateway is able to change its size under various physiological and pathological conditions. For instance, an earlier study (Madara, 1983) showed that increases in guinea pig intestinal transepithelial resistance induced by osmotic loads were accompanied by alterations in absorptive-cell tight junction structure. This alteration in intestinal permeability after meal ingestion enhances the ability of the small intestine to harvest the maximal amount of nutrients, as well as also increase the risk of exposure to luminal proinflammatory compounds. Tight junctions are also composed of other structural proteins including actin anchoring protein (ZO-1) and occludin, which could be the target of oxidative or other toxin injury and result in disruption of gastrointestinal barrier integrity (Farhadi et al., 2003; Nusrat et al., 2001). 


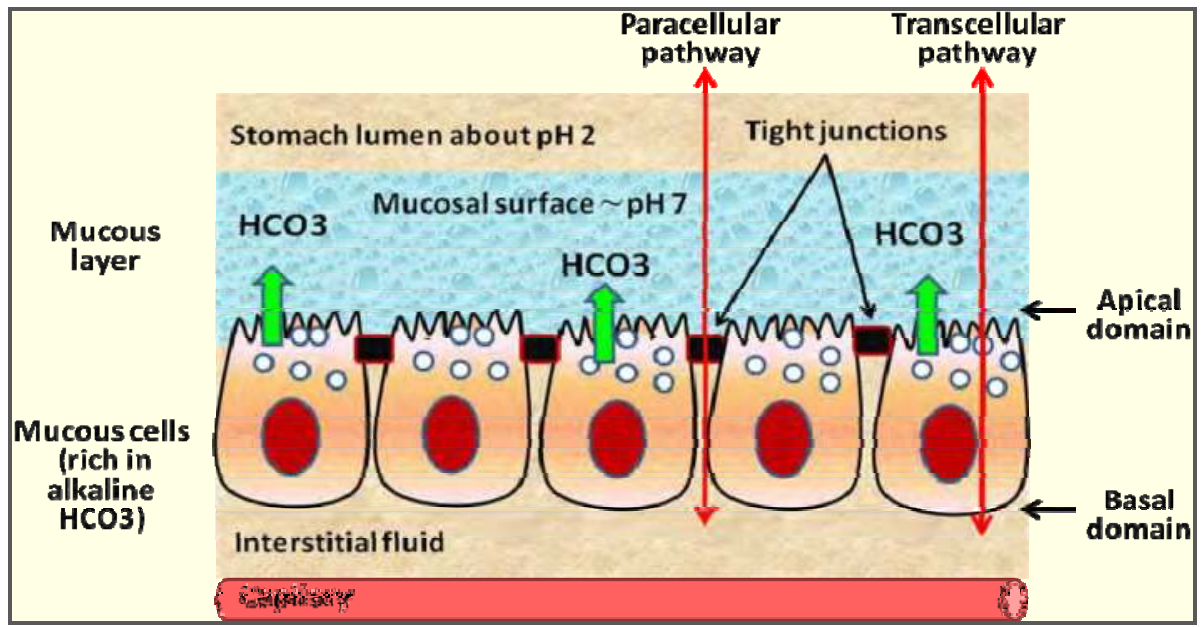

Fig. 1. Bicarbonate rich mucous secreted by surface epithelial cells.

Heat shock proteins generated by gastric epithelial cells are essential for the maintenance of cellular homeostasis during normal cell growth and for survival during various cellular stresses, such as increased temperature, oxidative stress, and cytotoxic agents, preventing protein denaturation and protecting cells against injury. Activation of heat shock protein response is one of the mucosal protective mechanisms of the antacid hydrotalcite. Also, cathelicidin and $B$ defensins are cationic peptides that play roles in the innate defensive system at mucosal surfaces preventing bacterial colonization. These elements have been demonstrated in gastric epithelial cells, and they accelerate ulcer healing (Tarnawski et al., 1999; Oyaka et al., 2006; Tanaka et al., 2007; Tulassay \& Herszényi, 2010).

The trefoil factor family (TFFs) comprises a group of small peptides (6.5-12 kDa) secreted abundantly by surface epithelium, which has been demonstrated play an important role in mucosal integrity (Taupin \& Podolsky, 2003). They regulate reepithelialization by stimulating cell migration and exert mucosal protective action from a broad range of toxic chemicals and drugs (Laine et al., 2008), as well as inhibiting apoptosis and inflammation, and augmenting the barrier function of mucus (Taupin \& Podolsky, 2003; Hernández et al., 2009; Tulassay \& Herszényi, 2010).

Maintenance of epithelial integrity requires a precise balance between cell proliferation and cell death. Thus, the epithelium is continually renewed by a well-coordinated and controlled proliferation of progenitor cells that enables replacement of damaged or aged surface epithelial cells. In this context, the gastric epithelium is populated by a variety of functionally-mature cells derived from proliferation of stem cells, such as mucous cells in the stomach, which show rapid turnover rates, and die within only a few days after their formation. Cell proliferation of progenitor cells is controlled by two peptides that have received attention for their potential role in barrier maintenance: epidermal growth factor (EGF), derived from salivary, esophageal and duodenal glands, and transforming growth factor alpha (TGF-alpha). Both peptides stimulate epithelial cell proliferation in case of injury as well as also enhance mucus secretion and inhibit acid production in the stomach (Murphy, 1998; Laine et al., 2008). However, after superficial injury, restitution of the surface epithelium occurs within minutes by migration of preserved epithelial cells located in the 
neck area of gastric glands. Such migration precedes and is independent of proliferation of progenitor cells, which occurs hours after injury (Lacy \& Ito, 1984; Blikslager \& Roberts, 1997; Laine et al., 2008).

Prostaglandins (PGs) are also synthesized by gastric mucosal epithelial cells from arachidonate metabolism through the action of cyclooxygenases (COX). The ability of exogenous PGs to attenuate or even completely prevent mucosal damage caused by corrosive substances such as absolute ethanol, concentrated bile or hiperosmolar solutions has been termed "cytoprotection" (Farhadi et al., 2003). Particularly prostaglandin E2 and prostacyclin have long been known to have "cytoprotective" effects on the gastrointestinal epithelium and therefore they can be crucial for the maintenance of the gastric integrity. In fact, it is well established that inhibition of their synthesis results in the reduction of gastric mucosal blood flow and gastric mucosal damage (Abdel Salam et al., 1997).

Thus, although the precise mechanism of cytoprotective action of prostaglandins remained unknown, it appears to result from a complex ability to stimulate mucosal mucus and bicarbonate secretion, to increase mucosal blood flow and sulfhydryl compounds and, particularly in the stomach, to limit back diffusion of acid into the epithelium (Tarnawski et al., 1985; Farhadi et al., 2003; Kato et al., 2005). Earlier studies confirm not only these finding but also document that certain growth factors, especially EGF, could be considered as gastroprotective because they were capable of reducing nonsteroidal anti-inflammatory drugs (NSAID)-induced gastric ulcerations in animals when endogenous PGs were completely inhibited by administration of these drugs (Konturek et a., 1981). Also, growth factors stimulated prostaglandin production in rat endometrial cells through a mechanism that involves an increase in cyclooxygenase activity (Bany \& Kennedy, 1995). Moreover, previous studies (Matsuda et al. 2002; Sánchez et al. 2006), including that conducted by our group (Silva et al., 2009), reported that endogenous prostaglandins are involved in the protective effect of different natural or semi-synthetic terpenes.

In addition, other mediators such as nitric oxide (NO), calcitonin gene related peptide (CGRP) as well as some hormones including gastrin and cholecystokinin (CCK), ghrelin, leptin and gastrin-releasing peptide (GRP) have been also found to protect gastric mucosa against the damage induced by corrosive substances. This protective action has also been attributed in part to the release of PGs because it could be abolished by the pretreatment with indomethacin (a nonselective inhibitor of COX 1 and 2) and restored by the addition of exogenous PGE2 (Farhadi et al., 2003).

\subsubsection{Subepithelial components (microcirculation and sensory innervations)}

The modulation of the gastric mucosal microcirculation plays an essential role in the maintenance of gastric integrity, especially for delivering oxygen and nutrients and removing toxic substances. At the level of the muscularis mucosae, most gastric arteries branch into capillaries, which enter the lamina propria and travel upward in proximity to gastric glandular epithelial cells. At the base of surface epithelial cells, capillaries converge into collecting venules (Laine et al., 2008; Tulassay \& Herszényi, 2010). Thus, blood flow is essential for many protective mechanisms. For instance, restitution, a process whereby denuded areas of the mucosa are covered by rapidly migrating cells from adjacent mucosa, depends to a large extent on adequate blood flow (Lacy \& Ito, 1984; Guttu et al., 1994; Abdel-Salam et al., 2001). Also, exposure of the gastric mucosa to an irritant or acid backdiffusion occurrence leads to a marked increase in mucosal blood flow. This increase allows 
removal and/or dilution of the back-diffusing acid and/or noxious agents and seems to be essential for mucosal defense because its abolition through mechanical restriction of blood flow leads to hemorrhagic necrosis (Holzer, 2006, Laine et al., 2008).

The endothelial cells are also able to generate potent vasodilators agents such as nitric oxide (NO) and prostacyclin (PGI2). NO is produced from L-arginine in a reaction catalyzed by the enzyme nitric oxide synthase (NOS) (Bredt \& Snyder, 1990). It is an important biological signaling molecule that influences circulation by regulating vascular smooth muscle tone and modulating systemic blood pressure. Therefore, it has been shown to exert positive effects on mucosal defense in the gastrointestinal system (Berg et al., 2004). Both NO and PGI2 oppose the mucosal damaging action of vasoconstrictors such as thromboxane A2, leukotriene C4, and endothelin. Consequently, these agents maintain viability of endothelial cells and prevent platelet and leukocyte adherence to the microvascular endothelial cells, preventing compromise of the microcirculation and thus protecting the gastric mucosa against injury (Laine et al., 2008). In addition to maintaining gastric blood flow, NO protects the gastrointestinal tract by inhibiting gastric acid secretion from parietal cells, stimulating mucus and bicarbonate secretion and by promotion angiogenesis in vivo and in vitro (Brown et al., 1993; Ma and Wallace, 2000).

Thus, for all its functions on gastric mucosal, NO has been shown to be beneficial in gastric ulcer healing. In fact, previous studies have demonstrated that NOS inhibition by $N(\mathrm{G})$ nitro- L-arginine (L-NNA) or N(G)-monomethyl-L-arginine (L-NMMA) significantly delayed ulcer healing, impaired angiogenesis in the granulation tissue and reduced gastric blood flow around the ulcer (Konturek et al., 1993). Also, NOS inhibitor N(G)-nitro-Larginine methyl ester (L-NAME) has been showed to increase ethanol-induced gastric lesions in mice (Bulut et al., 1999; Silva et al., 2009). On the other hand, administration of an NO donor (glyceryl trinitrate) or L-arginine (the substrate of NOS) significantly reverses NOS inhibitor induced delayed healing and enhances healing (Elliott et al., 1995; Brzozowski et al., 1995; Moura Rocha et al.; 2010).

In addition to local mucosal protection factors, gastric mucosal defense is also regulated, at least in part, by the central nervous system and hormonal factors (Stroff et al., 1995; Peskar, 2001; Mózsik et al., 2001). Gastric mucosa and submucosal vessels are innervated by primary afferent sensory neurons and nerves forming a dense plexus at the mucosal base. Afferent neurons constitute an emergency system that is requested when the gastric mucosa is endangered by noxious agents. Thus, activation of these nerves in presence of gastric acid promotes releasing of neurotransmitters such as substance $\mathrm{P}$ and calcitonin gene-related peptide (CGRP), which relax the smooth muscle surrounding the arterioles, resulting in an elevation of mucosal blood flow, increase in mucus gel and surface cell intracellular $\mathrm{pH}$ in stomach. This mucosal protective action occurs most likely through vasodilatation of submucosal vessels mediated by NO generation. In this sense, interference with any aspect of the sensory innervations impairs the hyperemic response and therefore diminishes resistance of the gastric mucosa to injury (Tanaka et al., 1997; Holzer, 2007; Laine et al., 2008; Tulassay \& Herszényi, 2010).

\section{Etiologies multiples of gastric ulcer development}

Despite its robust and multi-faceted nature, many factors directly related to impairment in mucosal defense can alter the epithelial barrier and encourage the formation of mucosal injury, the most important of which are acid secretion, bacteria and their products, non- 
steroidal anti-inflammatory drugs, alcohol, reactive oxygen species, as well as different chemical compounds. Their effects on the gastric barrier represent important mechanisms of the pathogenesis of gastric ulcers, chronic gastritis and other gastric diseases, which are frequently generated through an imbalance between mucosal aggressive and defensive factors (Figure 2) (Wallace, 1992; Peskar \& Marici, 1998; Tulassay \& Herszényi, 2010).

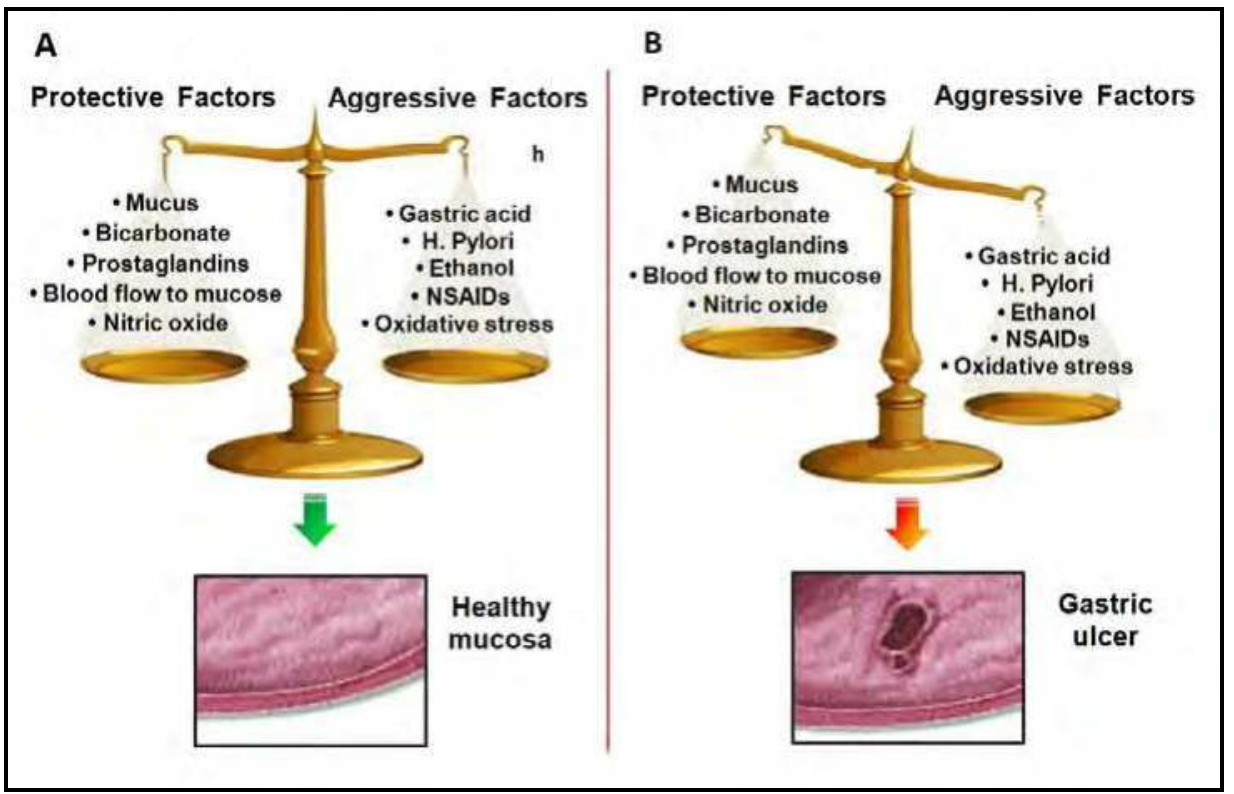

Fig. 2. (A) Healthy gastric mucosa: balance between mucosal aggressive and protective factors. (B) Gastric ulcer formation: imbalance between mucosal aggressive and protective factors.

\subsection{Helicobacter Pylori}

Helicobacter pylori is a common human pathogen and public health problem associated with the pathogenesis of gastritis and peptic ulcers. With a prevalence of up to $90 \%$ in developing populations, this microorganism is the second most common pathogen for human beings. It is a nonsporulating, gram-negative microaerophilic bacilli, spiral-shaped, having one to six polar-sheathed flagellae emerging from one of its rounded ends and a smooth surface (Dye et al.; 1989). This pathogen multiplies with great efficiency in the hostile environment within the stomach but survives poorly in the gastric lumen. It is mainly found under the mucous layer and in close proximity, or even attached, to gastric superficial epithelial cells, without substantial invasion of host tissue (Dubois, 1995).

H. pylori induces chronic gastritis of varying severity in infected subjects, which in around $10-15 \%$ progresses to peptic ulcer, while in $1-2 \%$ of subjects ultimately results in MALT lymphoma or gastric adenocarcinoma. The initial response to infection is an interaction of the host epithelial cells with the bacteria, however, the pathogenetic mechanisms of chronic infection with $H$. pylori and gastric ulcer are yet to be full determined (Parsonnet et al., 1991; Ernst \& Gold, 2000; Calvino-Fernández \& Parra-Cid, 2010). 
A characteristics feature of this pathogen is the synthesis of urease, which was its first virulence factor studied. This enzyme may explain the extraordinary ability of bacteria to colonize the gastric mucosa and survive in an acid environment (Smoot, 1991). Because the ecologic niches of these bacteria are rich in urea, it catalyzes urea hydrolysis with the formation of ammonium (NH3), carbon dioxide and hydroxyl ions. By this mechanism, $H$. pylori neutralizes the surrounding gastric acid and protects itself from the strong acidicity of the stomach (Smoot, 1991). On the other hand, although the neutralization of gastric acid benefits the bacteria, metabolites from urease activity are toxic to gastric epithelial cells (Figure 3). The formed ammonium reacts with $\mathrm{OCl}^{-}$produced by activated neutrophils to form highly toxic monochloramine $(\mathrm{NH} 2 \mathrm{Cl})$ in the stomach, a hallmark of $H$. pylori infection. In fact, inhibition of $H$. pylori urease has been showed significantly decrease this toxicity, suggesting that ammonia is at least partially responsible for the cytotoxicity found in association with this bacterium. Moreover, hydroxide ions are also considered toxic to gastric epithelial cells (Smoot, 1991; Handa et al., 2010).

Besides urease activity, further important virulence factors from $H$. pylori are their spiral shape and the motility of their flagellae, which render them resistant to peristaltic flushing of the gastric contents and enable them to persist in the mucous layer. Additionally, this pathogen produces other enzymes including catalase, oxidase, protease, and phospholipase, as well as it synthesizes specific adhesion proteins that enable them to adhere to mucous and epithelial cells (Boren et al., 1993; Dubois, 1995). In this context, although H. pylori typically colonizes the human stomach for many decades without adverse consequences, as referred above, the presence of this pathogen is associated with an increased risk of several diseases, including peptic ulcers, noncardia gastric adenocarcinoma, and gastric mucosa associated lymphoid tissue (MALT) lymphoma (Cover \& Blaser, 2009).

The risks of developing gastric diseases are determined in part by the presence or absence of specific genotypes of the H. pylori strains with which an individual is colonized. For that reason, $H$. pylori pathogenicity may differ with respect to each of its virulence factors and this diversity is likely to contribute to variation in colonization or disease. (Dubois, 1995; Marshall \& Windsor, 2005; Cover \& Blaser, 2009). Thus, a number of H pylori strains can express multiple factors that interact with host tissue and therefore are associated with increased gastric mucosal inflammatory cell infiltration and increased gastric epithelial injury, whereas strains that lack these factors would be relatively noninteractive with the host. When virulent $H$. pylori strains are present, organisms adhere to the gastric epithelium, which disrupts membrane integrity and induces host cells to release toxic proteins, cytotoxins, platelet activating factor, , and lipopolysaccharides that all further damage the gastric mucosa. These changes would accelerate apoptosis and proliferation in the mucosal layer (Figure 3) (Crabtree, 1996; Kohda et al., 1999; Makola et al., 2007). However, it has been shown that this inflammation resolves after eradication of the infection, and presumably the concentrations of the pro-inflammatory and antisecretory cytokines also decrease. Thus, once the eradication of the bacterium is always followed by resolution of gastritis, the aim of treatment is eradication of the pathogen, defined as negative tests for the organism for one month after completion of the course of the antimicrobial (Pakodi et al., 2000; Kuipers et al., 2003; Brzozowski, et al., 2006).

Although much research and understanding have been gained in the last decades since the discovery of $H$. pylori, more questions have been raised than answered. The long road towards deciphering the fundamental mechanisms underlying the development of gastritis, 
intestinal metaplasia and gastric cancer has only just begun. Thus, currently it is apparent that infection with $H$. pylori negatively influences several of the important defense mechanisms in the gastric barrier, however, the exact mechanisms leading to the development of pathological changes by $H$. pylori remain to be further investigated.
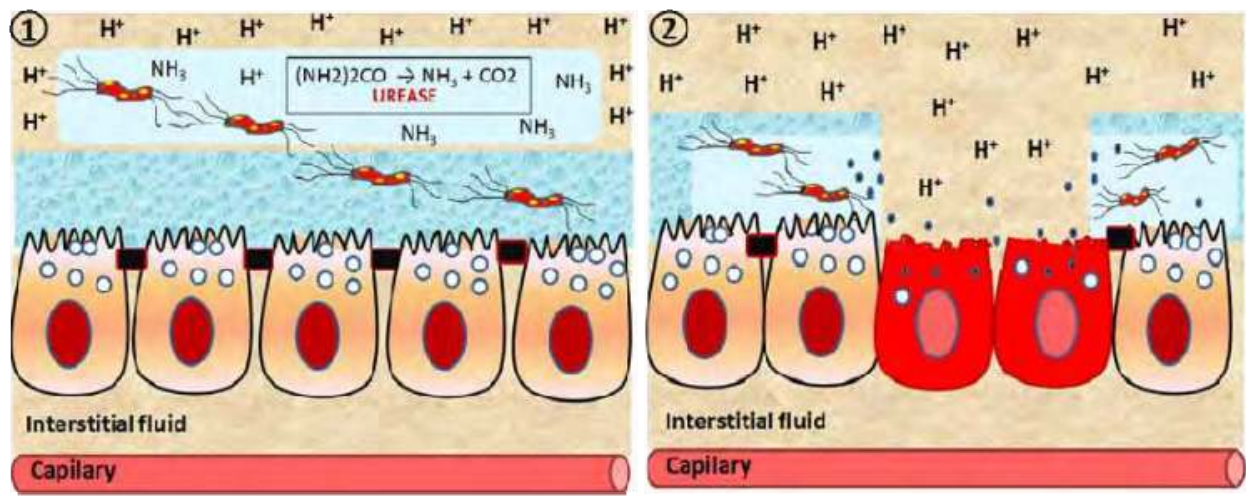

Fig. 3. Gastric ulcer formatted by Helicobacter pylori. (1) H. pylori catalyzes urea hydrolysis with the formation of ammonium (NH3) that neutralizes the surrounding gastric acid and protects itself from the strong acidicity of the stomach. (2) H. pylori penetrates the mucus layer of stomach, adhere the surface of gastric mucosal epithelial cells, prolifirate and finally form the infectious focus. The gastric lesion is developed by destruction of mucosa, inflammation and mucosal cell death.

\subsection{Non-steroidal anti-inflammatory drugs (NSAIDs)}

Another important factor directly related to gastric injury initiated by impairment in mucosal defense is the prominent non-steroidal anti-inflammatory drugs (NSAIDs) use. As the prevalence of $H$. pylori infection has declined, because of continued efforts to eradicate the organism, the prevalence of NSAID-induced ulcers has risen and is taking on greater clinical importance. Studies show that NSAIDs are among the most commonly used drugs in the world. In United States, approximately 70 million prescriptions are written each year, while in Europe these medications represent more than $7.7 \%$ of all prescriptions (Graumlich, 2001; Jones, 2001). NSAIDs use is more frequent among women and increases with age, as does the incidence of rheumatic diseases. In fact, more than $90 \%$ of prescriptions for NSAIDs are made to patients aged $>65$ years. The major problem with the use of these drugs is that they induce predictable gastric mucosal injury, including complications in both upper and lower gastrointestinal tract (Laine et al., 2008; Sostres et al., 2010).

The major mechanism via which NSAIDs cause ulcers and gastrointestinal complications is thought to be by inhibition of cyclooxygenase (COX), a key enzyme in the biosynthesis of prostaglandins (PGs). There are two well identified isoforms of COX, COX 1 and COX 2 (Laine et al., 2008; Sostres et al., 2010). COX 1 isoform is expressed in most tissues, producing prostaglandins that play an essential protective role in the stomach by stimulating the synthesis and secretion of mucus and bicarbonate, increasing mucosal blood flow and promoting epithelial proliferation. So, the COX-1-mediated PG synthesis is mainly responsible for maintaining gastric mucosal integrity at baseline. On the other hand, COX2 
has little or no expression in most tissues but is rapidly induced in response to inflammatory stimuli. Therefore, this isoform is the primary target for anti-inflammatory drugs.

In this context, the traditional NSAIDs nonselective inhibitors of both COX-1 and COX-2, such as indomethacin or ibuprofen, cause damage in the stomach with a marked decrease in the gastric mucosal PGE2 content. This effect occurs via COX 1 isoform inhibition, creating a gastric environment that is more susceptible to topical attack by endogenous and exogenous factors (Vane \& Botting, 1995). Moreover, the inhibition of the COX 1 blocks platelet production of thromboxane, which increases bleeding when an active gastrointestinal bleeding site is present (Lanas \& Scheiman, 2007; Sostres et al., 2010). This contention was further supported by the fact that COX-2 selective inhibitors, which do not inhibit COX-1 at therapeutic doses, do not affect the mucosal PGs production and do not produce gross gastric damage in experimental models (Laine et al., 2008).

Therefore, the development of NSAIDs which selectively inhibit COX-2 (Coxibs), while having little to no effect on COX-1, should result in effective pain relief with reduced adverse gastrointestinal effects. In fact, data from large gastrointestinal outcomes studies reveal that Coxibs significantly decrease gastroduodenal ulcers as compared with nonselective NSAIDs. Ulcer rates were significantly decreased with 5 tested Coxibs (celecoxib, valdecoxib, rofecoxib, lumiracoxib, etoricoxib) and when these drugs were tested against any of the most commonly used NSAIDs (diclofenac, naproxen or ibuprofen) (Rostom et al., 2007). Large randomized controlled outcome trials demonstrate a considerable reduction in upper gastrointestinal complications and overall upper gastrointestinal clinical events with Coxibs compared to traditional NSAIDs (Silverstein et al., 2000; Laine et al., 2007). Moreover, the results of another large outcomes study, celecoxib vs naproxen and diclofenac in osteoarthritis patients, confirmed the significantly better safety profile of celecoxib compared with traditional NSAIDs (Singh et al., 2006).

However, has been recognized that prostaglandins derived from COX-2 can be generated at the ulcer margin and appear to play an important role in ulcer healing through triggering the cell proliferation, promotion of angiogenesis and restoration of mucosal integrity (Konturek et al., 2005, Sostres et al., 2010). These observations indicate that, in contrast to the initial concept, COX-2 plays an important role in gastric mucosal defense. Accordingly to this, experimental studies have reported that inhibition of both COX-1 and COX-2 is required for NSAID-induced gastric injury (Wallace et al., 2000; Tanaka et al., 2001; Peskar et al., 2001) and therefore Coxibs markedly decrease but do not eliminate NSAIDs associated gastric and duodenal ulceration (Silverstein et al, 2000; Sostres et al., 2010). In fact, indomethacin and similar NSAIDs, which inhibit both isoforms of the COX enzyme, produce more severe damage in gastric tissue, even gastrointestinal bleeding, than more selective drugs (Delaney et al., 2007). Therefore, indomethacin became one of the first choice drugs to produce an experimental ulcer model (Sigthorsson et al., 2000; Suleyman et al., 2004). In this sense, the fact that nimesulide, which is considered to be less selective for COX-2 compared to Coxibs, is able to inhibit NSAID-induced gastric damage, while Coxibs agents (more selective for COX-2) are unable to inhibit these ulcers, indicates that it is impossible to attribute the gastrointestinal side effects of indomethacin and other NSAIDs to the inhibition of only the COX-1 enzyme (Suleyman et al., 2002).

In addition, studies have evidenced that NSAIDs may induce tissue and cell injury by mechanisms independent of prostaglandin inhibition, which include the inhibition of phosphorylating enzymes (kinases), inhibition of oxidative phosphorylation in 
mitochondria, and/or activation of apoptosis (Husain et al., 2001). These mechanisms, in combination with those related to prostaglandin suppression, lead to microvessel occlusion and subsequent hyperproduction of reactive oxygen metabolites. Such agents are then able to induce oxidative tissue injury that seems to play a prominent role in the development of mucosal ulceration caused by NSAIDs (Blandizzi et al., 2005). Furthermore, with the decrease in arachidonic acid metabolism via the COX pathway in NSAID users, arachidonic acid metabolism may be shifted to the alternative 5-lipoxygenase pathway, with a resultant increase in leukotriene production. In this way, a potential role for leukotrienes in NSAID induced gastric injury also has been postulated, since licofelone, an inhibitor of COX-1, COX-2, and 5-lipoxygenase, did not increase gastric mucosal injury (Bias et al., 2004).

Thus, because the prevalence and severity of NSAID-related gastrointestinal complications, recent efforts have been directed at the prevention of mucosal injury induced by these agents. In this sense, since NSAID and even Coxibs therapy delay the healing of active peptic ulcers, the best way to prevent mucosal injury is to avoid the use of NSAIDs or replace it with an agent less toxic to the gastroduodenal mucosa (Sostres et al., 2010).

\subsection{Gastric acid secretion}

For decades, surgeons were taught and believed that peptic ulcer disease was caused by acid, since the cure rate of peptic ulcer disease by acid-reduction operations (such as partial gastrectomies, gastroenterostomies or vagotomies) was substantial, impressive, and reported in the literature repeatedly, as described by Latarjet (1922) and Herrington et al. (1984). Thus, acid was meticulously measured in an attempt to better understand and treat peptic ulcer disease, the major clinical challenge at that time (Dotevall \& Walan, 1971). In this sense, when pharmacologic means were developed such as histamine-2 blockers drugs (like cimetidine), which effectively eliminated acid and thus many patients found that their ulcer disease was healed, these observations validated the dictum "no acid, no ulcer" (Gustafson and Welling, 2010).

Over time, the prevalence as well as the management of these disorders has changed. With the advent of newer pharmacological therapy (potent antisecretory medications such as proton pump inhibitors) and the understanding of the role of Helicobacter pylori in the pathogenesis of peptic ulcer disease, more ulcers were successfully treated medically and the number of surgical cases drastically decreased (Lorentzon et al., 1987; Lindberg et al., 1990; Meyer-Rosberg et al., 1996; Fock et al., 2008; Schubert \& Peura, 2008). As a result, the quantitative measurement of gastric acid secretion, for the most part, has become obsolete. Nevertheless, although there are multiple processes involved in the development of gastric lesions, the presence of acid hypersecretion continues to be a necessary condition for ulcer production and for a variety of common gastrointestinal disorders, since medical therapy for these illnesses involves both removing the injurious agent (eg, NSAIDs or H. pilory) and inhibiting acid secretion (Richardson et al., 1998; Schubert \& Peura, 2008).

Parietal cells secrete hydrochloric acid at a concentration of approximately $160 \mathrm{mmol} / \mathrm{L}$ or $\mathrm{pH}$ 0.8. Acid facilitates the digestion of proteins and absorption of calcium, iron, and vitamin B-12, as well as it is the first line of mucosal defense to avoid microorganisms colonization thus preventing the bacterial overgrowth and consequent enteric infection (such as by Helicobacter pylori). However, when levels of acid (and pepsin) overwhelm mucosal defense mechanisms, common and potentially serious acid-related clinical conditions occur, including gastroesophageal reflux disease, Barrett's esophagus, where the 
usual squamous mucosal lining becomes replaced by columnar epithelial cells of putative specific aspect, peptic ulcer disease, and stress-related erosion/ulcer disease (Schubert \& Peura, 2008; Schubert, 2008).

Acid is thought to gain access to the lumen by means of channels in the mucus layer created by the relatively high intraglandular hydrostatic pressures generated during secretion (approximately $17 \mathrm{~mm} \mathrm{Hg}$ ) (Johansson et al., 2001). Thus, luminal acid interferes with the process of restitution, resulting in the conversion of superficial injury to deeper mucosal lesion and inactivates the acid-labile growth factors important for maintenance of mucosal integrity and repair of superficial injury. A large amount of studies show that the rate of acid secretion by the human stomach changes little with aging unless there is coexisting disease of the oxyntic mucosa such as atrophic gastritis, infection with $H$. pylori or both (Trey et al., 1997; Schubert \& Peura, 2008).

To prevent acid-induced mucosal damage, gastric acid must be precisely regulated through a highly coordinated interaction of neural, hormonal, and paracrine pathways (Schubert \& Peura, 2008). In this sense, the principal stimulants of acid secretion include gastrin, histamine, gastrin-releasing peptide (GRP), orexin, ghrelin, and glucocorticoids, while the main inhibitor is somatostatin, released from oxyntic and pyloric D cells (paracrine). Gastrin, released from antral G cells into the blood stream during meals, stimulates acid secretion primarily by releasing histamine from histaminesecreting enterochromaffin-like (ECL) cells. GRP, released from antral nerve fibers in response to proteins, stimulates gastrin secretion. Ghrelin and orexin appear to stimulate acid secretion, although their physiologic roles in the stomach are not known. Glucocorticoids stimulate acid secretion acting via phosphoinositide 3 kinase, serum-inducible kinase and glucocorticoid-inducible kinase (Schubert, 2008). In addition, acetylcholine (Ach), released from postganglionic enteric neurons (neuronal stimulation), acts directly stimulating parietal cell acid secretion, as well as indirectly, by eliminating the inhibitory paracrine influence of somatostatin on parietal and ECL cells (Chuang et al., 1993; Schubert, 2008; Schubert \& Peura, 2008).

Acid secretion by the parietal cell involves intracellular elevation of calcium, cyclic AMP, or both followed by a cascade that triggers the translocation of the proton pump, $\mathrm{H}^{+} \mathrm{K}^{+}-$ ATPase, from cytoplasmic tubulovesicles to the apical plasma membrane. This pump is an integral membrane protein that transports hydronium ions from the cytoplasm into the canaliculus of the parietal cell in exchange for potassium. Most of the adult population chronically infected with $H$. pylori produce less than normal amounts of acid probably due to increased apoptosis via secreted mediators (such as VacA cytotoxin and lipopolysaccharide), induction of proinflammatory mediators (such as IL-1b), and inhibition of the $\mathrm{H}^{+} \mathrm{K}^{+}$-ATPase activity (Schubert, 2008). This condition may cause further reduction of acid production and, eventually, atrophy of the stomach lining, which may lead not only gastric ulcer but also increased risk for stomach cancer (Suerbaum \& Michetti, 2002; Peek \& Crabtree, 2006). Conversely, approximately $10 \%$ to $15 \%$ of patients chronically infected with this pathogen have antral predominant inflammation and are predisposed to duodenal ulcer. They produce increased amounts of acid as a result of reduced antral somatostatin content and elevated basal and stimulated gastrin secretion. Gastrin stimulates the parietal cells in the corpus to secrete even more acid into the stomach lumen and chronically may cause the number of parietal cells to also increase. The increased acid load ulcerations the duodenum (El-Omar, 2006; Schubert \& Peura, 2008).

Thus, dosed before mealtime, proton pump inhibitors drugs are the most effective acid inhibitors currently available and are the most widely prescribed class of gastrointestinal 
medications. Not only can peptic ulcers be healed more rapidly with these agents, but refractory ulcers have all but disappeared. However, many clinical studies do support an accelerating effect of proton pump inhibitors on the development of atrophic gastritis in $H$. pylori-positive patients, while other evidences suggest that long-term acid suppression would result in relatively greater bacterial colonization in the corpus leading to diffuse or corpus-predominant gastritis or to acute gastroenteritis (Moayyedi et al., 2000; Rosh \& Hassall, 2006; Schubert, 2008). Such observations have important implications given the extensive use of these drugs worldwide. Thus, continued progress in understanding of gastric acid secretion in health and disease is needed and this knowledge will be used to develop new more effective strategies to prevent and manage gastric disorders.

\subsection{Alcohol}

Throughout the world, alcohol has been used for centuries in social, medical, cultural, and religious settings. Currently, it is considered to be one of the most commonly abused drugs, related to a wide range of physical, mental, and social harms, and responsible for $3.8 \%$ of deaths and $4.6 \%$ of disability-adjusted life years lost worldwide. The World Health Organization (WHO) has estimated that there are about 2 billion people worldwide who consume alcoholic beverages and 76.3 million with diagnosable alcohol use disorders (Stermer, 2002; WHO, 2004, 2008; Rehm et al., 2009).

Among the various organ systems that mediate alcohol's effects on the human body and its health, the gastrointestinal tract plays a particularly important role. The alcohol absorption into the bloodstream occurs throughout the gastrointestinal tract and its direct contact with the mucosa can induce numerous metabolic and functional changes. These alterations may lead to marked mucosal damage, which can result in a broad spectrum of acute and chronic diseases, such as gastrointestinal bleeding and ulcers (Bode \& Bode, 1997). In this context, pathogenesis of ethanol-induced gastric lesions is complex. Alcohol may interact directly with the gastric mucosa or it may act through a more general mechanism affecting the release of hormones and the regulation of nerve functions involved in acid secretion (Bode \& Bode, 1997; Chari et al. 1993).

Intragastric application of absolute ethanol has long been used as a reproducible method to induce gastric mucosa lesions in experimental animals (Szabo et al., 1981; Arafa \& SayedAhmed, 2003). The effects of acute administration of absolute ethanol to rats and mice on the gastric mucosa are dose-dependent and the damage appears as early as 30 minutes after ingestion and reaches a peak at about 60 minutes. The ethanol-induced gastric musosal lesions and erosions are similar to those occurring in gastric ulcer (Stermer, 2002; Repetto \& Llesuy, 2002). Thus, alcoholic gastritis leads to the impairment of the integrity of gastric mucosal barrier, contributing to acid reflux into the subluminal layers of the mucosa and submucosa (Oh et al., 2005).

Chari et al. (1993) relate that intravenous, oral, and intragastric alcohol at a concentration of up to $5 \%$ increases acid secretion principally by stimulating the secretion of gastrin and to a lesser extent by a direct effect on the parietal cells. On the other hand, an alcohol concentration of higher than $5 \%$ has no effect on gastric acid secretion (Stermer, 2002). Also, oxidative stress and depletion of non-protein sulfhydryls concentration, modulation of nitric oxide system and reduction of gastric mucosal blood flow frequently underlie the development of gastric lesions (Arafa \& Sayed-Ahmed, 2003). According to Bode et al. (1996), the decreased formation of prostaglandins might also play a role in alcohol-induced 
mucosal injury, while other studies have indicated that an alcohol-dependent increase in the production of leukotrienes also might contribute to the development of alcohol-induced damage. It is important emphasize that changes induced by short-term exposure to alcoholic beverages are rapidly reversible while prolonged alcohol exposure leads to progressive structural mucosal damage (Bode \& Bode, 1997).

Oxidative stress and depletion of anti-oxidants have been considered a crucial step in alcohol-induced mucosal damage and so they have been widely investigated in a number of studies (Hirokawa 1998; La Casa et al., 2000; Arafa \& Sayed-Ahmed, 2003). Ethanol treatment induces intracellular oxidative stress and produces mitochondrial permeability transition and mitochondrial depolarization, which precede cell death in gastric mucosal cells. Thus, considering that ethanol is involved in the formation of oxidative stress generated extracellularly and/or intracellylary, the cytoprotective role of anti-oxidants in the prevention and healing of gastric lesions has also been widely investigated (Santos \& Rao, 2001; Silva et al., 2009). In this sense, various studies point to intracellular antioxidants, such as glutathione (an endogenous sulfhydryl compound, as described below), as significant protective agents against ethanol in gastric mucosal cells (Repetto \& Llesuy, 2002). Intragastric administration of superoxide dismutase was also able to protect the gastric mucosa against the damaging effect of ethanol (Terano et al., 1989). Also, ethanolinduced oxidative stress may account for the decreased NO release, because NO may be shunted toward scavenging free radicals. In this context, response to ethanol was prevented by increased production of nitric oxide and inducible NOS (Kato et al., 2000). In addition to ethanol-induced gastrointestinal tract alterations, alcohol consumption has been linked to increased risk of tumors in the pharynx, esophagus, stomach and colon (Stermer, 2002).

\subsection{Oxidative stress}

It is well documented in the literature that reactive oxygen species (ROS), such as superoxide anions, hydrogen peroxide, and hydroxyl radicals, are involved in the etiology and physiopathology of several human diseases including neurodegenerative disorders, viral infections, inflammation, autoimmune pathologies, as well as in digestive disturbances such as gastrointestinal inflammation and gastric ulcer (Repetto \& Llesuy, 2002).

During gastric oxidative stress, the imbalance of aggressive and defensive factors in the stomach plays a pivotal role in gastric hemorrhage and ulcer formation (Hung, 2005). Overproduction of ROS has been concerned as one of the major pathogenic factors that directly results in oxidative damage, including lipid peroxidation, protein oxidation, and DNA damage, which can lead to cell death. Additionally, these agents are known to act as second messengers to activate diverse redox-sensitive signaling transduction cascades, including mitogen-activated protein kinases (MAPKs) and downstream transcription factors such as NF-kB and AP-1, which regulate the expression of several pro-inflammatory genes and, thereby, lead to the elaboration of chemical and humoral mediators of tissue inflammation and injury (Sun \& Oberley, 1996; Ali \& Harty, 2009). This is frequently evidenced by pro-ulcerative factors in the stomach and gut such as H pylori, use of NSAIDs, ethanol, smoking, psychological stress, corticosteroid use, and loss of sleep, while defensive factors involve glutathione (GSH), an important endogenous sulfhydryl compound, and mucus biosynthesis (Hung, 2005; Olaleye et al., 2007).

In the illness state, oxidative stress of the stomach may occur and result in an elevation of mucosal lipid peroxide that are generated from the reaction of oxyradicals and cellular 
polyunsaturated fatty acid, while GSH may act to prevent this aggressive action that can damage gastric mucosal cells. Malondialdehyde (MDA) is an end product resulting from peroxidation of polyunsaturated fatty acids and related esters within cell membranes, and the measurement of this substance represents a suitable index of oxidative tissue damage. On the other hand, sulfhydryl compounds such as GSH are involved in the maintenance of gastric integrity, particularly when reactive oxygen species are implicated in the pathophysiology of tissue injury (Blandizzi et al., 2005). Thus, the appearance of lipid free radicals and MDA in the blood and gastric juice could result from ROS-initiated chain reactions or initiated by indirect mechanisms that suppress the antioxidant capacity in both blood and gastric wall to scavenge ROS (Dotan et al., 2004; Tuorkey \& Abdul-Aziz, 2011). In fact, numerous studies have demonstrated a decrease in GSH level in inflammatory and ulcerated gastric mucosa, as well as the protective effect of GSH on gastric damage induced by ethanol, nonsteroidal anti-inflammatory drugs, or lipopolysaccharide has been well documented (Hung, 2000; Hung, 2005; Silva et al., 2009; Al-Hashem, 2010).

On the other hand, a large body of research in both animal and human studies has examined the effect of psychological stress on the gastrointestinal tract. For instance, in accordance to Levenstein et al., (1999), susceptibility to gastric lesions is increased in rats by social stressors as premature separation of the rat pup from its mother (Ackerman et al., 1975). Also, subjects with psychological distress, self-described "stress or strain," or concrete life stressors at baseline have increased incidence of ulcer over 9 to 15 years (Levenstein et al., 1995; Levenstein et al., 1999). In this sense, according to Chang (2008), stressors can be acute or chronic and range from daily hassles to life-threatening situations like natural disasters and violence that trigger the "fight or flight" response. Over time, recurrent stress results in an increase demand on physiologic systems. Thus, several terms have been used to describe stress-related mucosal damage in critically ill patients, including stress ulcers, stress gastritis, stress erosions, hemorrhagic gastritis, erosive gastritis, and stress-related mucosal disease (Ali \& Harty, 2009).

Stimulation of gastric acid secretion has historically been considered a mechanism by which physiological stress increases susceptibility to gastroduodenal ulceration. It is also known to modify gastric blood flow, which plays an important role in the gastric mucosal barrier, and to affect possible mediators such as cytokines, corticotropin-releasing hormone and thyrotropin- releasing hormone. Furthermore, stress seems to have different effects on gastric motility including delayed gastric emptying, which could increase the risk of gastric ulcer, while accelerated emptying could increase the net acid load delivered to the duodenum, enhancing the risk of duodenal ulcer. Psychological stress may also promote the growth of $H$. pylori in the duodenum if it increases duodenal acid load, since the $H$. pyloriinhibitory effects of bile seem to be reversed by acid (Levenstein et al., 1999).

\section{Conclusion}

Despite continuous exposure to several noxious factors, under normal conditions the gastric mucosa is able to maintain structural integrity and function. However, gastric mucosal injuries may occur when harmful factors overcome an intact mucosal defense or when the mucosal defensive mechanisms are impaired. Thus, much importance is attached to interactions and relationships among various ulcer-related factors, as well as to the individuality of the patients, including infections by H. pylori, alcohol and NSAIDs consume, and even smoking use, or stress-related disease. 
Significant knowledge over the past three decades regarding gastric mucosal attack and defense mechanisms has led to the development of current and potential future therapies to reduce gastrointestinal injury and improve the quality of ulcer healing. Therefore, the incidence of gastric ulcers has declined, possibly as a result of the increasing use of proton pump inhibitors and decreasing rates of Helicobacter pylori infection. However, although there are many studies on gastroprotective therapies, their clinical effectiveness remains unclear. Thus, because gastric ulcer is a multifactorial disease, its medical management should not be based on a simple cause-effect relationship, instead a bio-psychosocial approach adjusted for the individual patient should be applied, with careful consideration of the association of this disease with many personal factors.

\section{References}

Abdel Salam, O.M.; Szolcsányi, J.; Mózsik. G. (1997). The indomethacin-induced gastric mucosal damage in rats. Effect of gastric acid, acid inhibition, capsaicin-type agents and prostacyclin. Journal of Physiology - Paris, Vol.91, No.1 (February), pp.7-19, ISSN 0928-4257.

Abdel-Salam, O.M.; Czimmer, J.; Debreceni, A.; Szolcsányi, J. \& Mózsik, G. (2001). Gastric mucosal integrity: gastric mucosal blood flow and microcirculation. An overview. Journal of Physiology (Paris), Vol.95, No.1-6 (January-December), pp.105-127, ISSN 0928-4257.

Ackerman, S.H.; Hofer, M.A. \& Weiner, H. (1973). Age at maternal separation and gastric erosion susceptibility in the rat. Psychosomatic Medicine, Vol.37, No.2 (MarchApril), pp. 180-184, ISSN 0033-3174.

Al-Hashem, F.H. (2010). Gastroprotective effects of aqueous extract of Chamomilla recutita against ethanol-induced gastric ulcers. Saudi Medical Journal. Vol.31, No.11 (November), pp. 1211-1216, ISSN 0379-5284.

Ali, T. \& Harty, R.F. (2009). Stress - Induced Ulcer Bleeding in Critically Ill Patients. Gastroenterology Clinics of North America 38, Vol.2 (June), pp. 245-265, ISSN 08898553.

Allen, A. \& Flemström, G. (2005). Gastroduodenal mucus bicarbonate barrier: protection against acid and pepsin. American Journal of Physiology - Cell Physiology, Vol.288, No.1 (January), pp.C1-C19, ISSN: 1522-1563.

Allen, A. \& Garner, A. (1980). Gastric mucus and bicarbonate secretion and their possible role in mucosal protection. Gut, Vol.21, No.3 (March), pp. 249-262, ISSN 00175749 .

Allen, A. (1978). Structure of gastrointestinal mucus and the viscous and gel forming properties of mucus. British Medical Bulletin, Vol.34, No.1 (January), pp. 28-33, ISSN 0007-1420.

Allen, A. (1989). Gastrointestinal mucus, In: Handbook of Physiology. Gastrointestinal Physiology. Salivary, Gastric, Pancreatic, and Hepatobiliary Secretion, M.D. Bethesda, Am. Physiol. Soc. (Ed), sect. 6, vol. III, chapt. 19, pp. 359-382, ISBN-10: 0195208161, ISBN-13: 978-0195208160.

Allen, A.; Pain, R.H., \& Robson, T. (1976). Model for the structure of gastric mucus gel. Nature, Vol.264 (November), p.88-89, ISSN 0028-0836. 
Arafa, H.M. \& Sayed-Ahmed, M.M. (2003). Protective role of carnitine esters against alcohol-induced gastric lesions in rats. Pharmacological Research, Vol.48, No.3 (September), pp. 285-90, ISSN 1043-6618.

Bany, B.M. \& Kennedy, T.G. (1995). Regulation by epidermal growth factor of prostaglandin production and cyclooxygenase activity in sensitized rat endometrial stromal cells in vitro. Journal of reproduction $\mathcal{E}$ fertility, Vol.104, No.1 (May), pp. 57-62, ISSN 0022-4251.

Berg, A.; Redeen, S.; Ericson, A. \& Sjöstrand, S.E. (2004). Nitric oxide-an endogenous inhibitor of gastric acid secretion in isolated human gastric glands. BMC Gastroenterology, Vol.6, (August), pp.4:16, ISSN 1471-230X.

Bias, P.; Buchner, A.; Klesser, B.; Laufer, S. (2004). The gastrointestinal tolerability of the LOX/COX inhibitor, licofelone, is similar to placebo and superior to naproxen therapy in healthy volunteers: results from a randomized, controlled trial. American journal of gastroenterology, Vol.99, No.4 (April), pp. 611-618, ISSN 00029270.

Blandizzi, C.; Fornai, M.; Colucci, R.; Natale, G.; Lubrano, V.; Vassalle, C.; Antonioli, L.; Lazzeri, G. \& Del Tacca, M. (2005). Lansoprazole prevents experimental gastric injury induced by non-steroidal anti-inflammatory drugs through a reduction of mucosal oxidative damage. World Journal of Gastroenterology, Vol.14;11, No.26 (July), pp. 4052-4060, ISSN 1007-9327.

Blikslager, A.T. (1997). Roberts MC: Mechanisms of intestinal mucosal repair. Journal of the American Veterinary Medical Association,Vol.1;211, No.11 (December), pp.14371441, ISSN 0003-1488.

Bode, C. \& Bode, J.C. (1997). Alcohol's role in gastrointestinal tract disorders. Alcohol Health \& Research World, Vol.21, No.1, pp. 76-83, ISSN 0090-838X.

Bode, C.; Maute, G. \& Bode, J.C. (1996). Prostaglandin E2 and prostaglandin F2 alpha biosynthesis in human gastric mucosa: Effect of chronic alcohol misuse. Gut, Vol.39, No.3 (September), pp. 348-352, ISSN 0017-5749.

Boren, T.; Falk, P.; Roth, K.A.; Larson, G. \& Normark, S. (1993). Attachment of Helicobacter pylori to human gastric epithelium mediated by blood group antigens. Science, Vol.17;262, No.5141 (December), pp. 1892-1895, ISSN 0036-8075.

Bredt, D.S. \& Snyder, S.H. (1990). Isolation of nitric oxide synthetase, a calmodulinrequiring enzyme. Proceedings of the National Academy of Sciences of the United States of America, Vol.87, No.2 (January), pp.682-685, ISSN 0027-8424.

Brown, J.F.; Kerates, A.C.; Hanson, P.J. \& Whittle, B.J.R. (1993). Nitric oxide generators and cGMP stimulate mucus secretion by gastric mucosal cells. American Journal of Physiology: Gastrointestinal and Liver Physiology, Vol.265, No.3 (September), pp.G418-G422, ISSN 0193-1857.

Brown, L.F. \& Wilson, D.E (1999). Gastroduodenal ulcers: causes, diagnosis, prevention and treatment. Comprehensive Therapy, Vol.25, No.1 (January), pp. 30-38, ISSN 0098-8243.

Brzozowski, T.; Konturek, S.J.; Drozdowicz, D.; Dembinski, A. \& Stachura, J. (1995). Healing of chronic gastric ulcerations by L-arginine. Role of nitric oxide, prostaglandins, gastrin and polyamines. Digestion 56, No.6, pp. 463-471, ISSN 0012-2823. 
Brzozowski,T.; Konturek, P.C.; Mierzwa, M.; Drozdowicz, D.; Bielanski, W.; Kwiecien, S.; Konturek, S.J.; Stachura, J.; Pawlik, W.W. \& Hahn, E.G. (2006). Effect of probiotics and triple eradication therapy on the cyclooxygenase (COX)-2 expression, apoptosis, and functional gastric mucosal impairment in Helicobacter pyloriinfected Mongolian gerbils. Helicobacter, Vol.11, No.1 (February), pp. 10-20, ISSN 1083-4389.

Bulut, R.; Unlucerci, Y; Bekpinar, S. \& Kuntsal, L. (1999). Nitric Oxide-Mediated Regulation of Gastric H+, K+-ATPase and Alcohol Dehydrogenase Following Ethanol-Induced Injury in Rats. Digestive diseases and sciences, Vol.44, No.7 (July), pp. 1417-1422, ISSN 0163-2116.

Calvino-Fernández, M. \& Parra-Cid, T. (2010). H. pylori and mitochondrial changes in epithelial cells. The role of oxidative stress. Revista Española de Enfermedades Digestivas (Madrid), Vol. 102, No 1 (January), pp. 41-50, ISSN 1130-0108.

Chang, L. (2008). The Role of Stress on Physiological Responses and Clinical Symptoms in Irritable Bowel Syndrome. Current Molecular Medicine, Vol.8, No.4, (June), pp. 299-312, ISSN 1566-5240.

Chari, S.; Teyssen, S.; and Singer, M.V. (1993). Alcohol and gastric acid secretion in humans. Gut, Vol.34, No.6 (June), pp. 843-847, ISSN 0017-5749.

Chuang, C.N.; Tanner, M.; Lloyd, K.C.K.; Wong, H.; Soll, A.H. (1993). Endogenous somatostatin inhibits histamine release from canine gastric mucosal cells in primary culture. American Journal of Physiology: Gastrointestinal and Liver Physiology, Vol.265, No.3 (September), pp.G521-G525, ISSN 0193-1857.

Cover, T.L. \& Blaser, M.J. (2009). Helicobacter pylori in Health and Disease. Gastroenterology, Vol.136, No.6 (May), pp. 1863-1873, ISSN 0016-5085.

Crabtree,J.E. (1996). Immune and inflammatory responses to Helicobacter pylori infection. Scandinavian Journal of Gastroenterology - Supplement, Vol.215, pp. 3-10, ISSN 00855928.

Darling, R.L.; Romero, J.J.; Dial, E.J.; Akunda, J.K.; Langenbach, R. \& Lichtenberger, L.M. (2004). The effects of aspirin on gastric mucosal integrity, surface hydrophobic, and prostaglandin metabolism in cyclooxygenase knockout mice. Gastroenterology, Vol.127, No.1 (July), pp.94-104, ISSN 0016-5085.

Delaney, J.A.; Opatrny, L.; Brophy, J.M. \& Suissa, S. (2007). Drug drug interactions between antithrombotic medications and the risk of gastrointestinal bleeding. Canadian Medical Association Journal, Vol.14;177, No.4 (August), pp. 347-351, ISSN 0820-3946.

Dimaline, R. \& Varro A. (2007). Attack and defence in the gastric epithelium - a delicate balance. Experimental Physiology, Vol.92, No.4 (July), pp.591-601, ISSN 0958-0670.

Dotan,Y.; Lichtenberg, D.; \& Pinchuk, I. (2004). Lipid peroxidation cannot be used as a universal criterion of oxidative stress. Progress in Lipid Research, Vol.43, No.3 (May), pp. 200-227, ISSN 0163-7827.

Dotevall, G. \& Walan, A. (1971). Clinical value of the gastric secretory test. Nordisk medicin, Vol. 11;86, No. 45 (November), pp. 1293-1297, ISSN 0029-1420.

Dubois, A. (1995). Spiral Bacteria in the Human Stomach: The Gastric Helicobacters. Emerging Infectious Diseases. Vol.1, No.3 (July-September), ISSN 1080-6059.

Dye, K.R.; Marshall, B.J.; Frierson, H.F.; Guerrant, R.L. \& McCallum, R.W. (1989). Ultrastructure of another spiral organism associated with human gastritis. 
Digestive Diseases and Sciences, Vol.34, No.11 (November), pp. 1787-1791, ISSN 0163-2116, 1573-2568.

Elliott, S.N.; McKnight, W.; Cirino, G. \& Wallace, J.L. (1995). A nitric oxide-releasing nonsteroidal anti-inflammatory drug accelerates gastric ulcer healing in rats. Gastroenterology, Vol.109, No.2 (August), pp. 524-530, ISSN 0016-5085.

El-Omar, E.M. (2006). Mechanisms of increased acid secretion after eradication of Helicobacter pylori infection. Gut, Vol.55, No.2 (February), pp. 144-146, ISSN 00175749 .

Ernst, P.B. \& Gold, B.D. (2000). The disease spectrum of Helicobacter pylori: the immunopathogenesis of gastroduodenal ulcer and gastric cancer. Annual Review of Microbiology, Vol.54, pp. 615-640, ISSN 0066-4227.

Farhadi, A.; Banan, A. \& Keshavarzian, A. (2003). Role of Cytoskeletal Structure in Modulation of Intestinal Permeability. Archives of Iranian Medicine, Vol.6, No.1 (January), pp. 49 - 53, ISSN 1029-2977.

Fock, K.M.; Ang, T.L.; Bee, L.C. \& Lee, E.J.D. (2008). Proton pump inhibitors: do differences in pharmacokinetics translate into differences in clinical outcomes? Clinical Pharmacokinetics, Vol.47, No.1, pp.1-6, ISSN 0312-5963.

Graumlich, J.F. Preventing gastrointestinal complications of NSAIDs. Postgraduate Medicine, Vol.109, No.5 (May), pp.117-120, 123-128, ISSN 0032-5481.

Gustafson, J. \& Welling, D. (2010). "No acid, no ulcer"--100 years later: a review of the history of peptic ulcer disease. Journal of the American College of Surgeons, Vol.210, No.1 (January), pp. 110-116, ISSN 1072-7515.

Guttu, K.; Sorbye, H.; Gislason, H.; Svanes, K. \& Gronbech, J.E. (1994). Role of bicarbonate in blood flow-mediated protection and repair of damaged gastric mucosa in the cat. Gastroenterology, Vol.107, No.1 (July), pp. 149-159, ISSN 0016-5085.

Handa, O.; Naito, Y. \& Yoshikawa, T. (2010). Helicobacter pylori: a ROS-inducing bacterial species in the stomach. Inflammation Research, Vol.59, No.12 (December), pp. 997-1003, ISSN 1023-3830.

Henriksnäs, J.; Phillipson, M.; Storm, M.; Engstrand, L.; Soleimani, M. \& Holm, L. (2006). Impaired mucus-bicarbonate barrier in Helicobacter pylori-infected mice. American Journal of Physiology: Gastrointestinal and Liver Physiology, Vol.291, No.3 (September), pp.G396-G403, ISSN 0193-1857.

Hernández, C.; Santamatilde, E.; McCreath, K.J.; Cervera, A.M.; Díez, I.; Ortiz-Masiá, D.; Martínez, N.; Calatayud, S.; Esplugues, J.V. \& Barrachina, M.D. (2009). Induction of trefoil factor (TFF)1, TFF2 and TFF3 by hypoxia is mediated by hypoxia inducible factor-1: implications for gastric mucosal healing. British Journal of Pharmacology, Vol.156, No.2 (January), pp.262-272, ISSN 0007-1188.

Hills, B.A.; Butler, B.D. \& Lichtenberger, L.M. (1983). Gastric mucosal barrier: hydrophobic lining to the lumen of the stomach. American Journal of Physiology, Vol.244, No.5 (May), pp.G561-G568, ISSN 1522-1539.

Hirokawa, M.; Miura, S.; Yoshida, H.; Kurose, I.; Shigematsu, T.; Hokari, R.; Higuchi, H.; Watanabe, N.; Yokoyama, Y.; Kimura, H.; Kato, S; \& Ishii, H. (1998). Oxidative stress and mitochondrial damage precedes gastric mucosal cell death induced by ethanol administration. Alcoholism: Clinical and Experimental Research, Vol.22, No.3 (May), pp. 111-114, ISSN 0145-6008. 
Holzer, P. (2006). Neural regulation of gastrointestinal blood flow. In: Physiology of the gastrointestinal tract, L.R. Johnson, (4th Ed.), 817-839, Academic Press, ISBN 0120883945, New York, EUA.

Holzer, P. (2007). Role of visceral afferent neurons in mucosal inflammation and defense. Current Opinion in Pharmacology, Vol.7, No.6 (December), pp.563-569, ISSN14714892.

Hung, C. (2005). Effect of lysozyme chloride on betel quid chewing aggravated gastric oxidative stress and hemorrhagic ulcer in diabetic rats. World Journal of Gastroenterology, Vol.11, No.37 (October), pp. 5853-5858, ISSN 1007-9327.

Hung, C.R. (2000). Importance of histamine, glutathione and oxyradicals in modulating gastric hemorrhagic ulcer in septic rats. Clinical and Experimental Pharmacology and Physiology 2000; 27: 306-312, ISSN 1440-1681.

Husain, S.S.; Szabo, I.L.; Pai, R.; Soreghan, B.; Jones, M.K.; Tarnawski, A.S. (2001). MAP (ERK-2) kinase - a key target for NSAIDs-induced inhibition of gastric cancer cell proliferation and growth. Life Sciences, Vol.9;69, No.25-26 (November), pp. 30453054, ISSN 0730-9384.

Johansson, M.; Synnerstad, I. \& Holm, L. (2001). Acid transport through channels in the mucous layer of rat stomach. Gastroenterology, Vol.119, No.5 (November), pp. 1297-1304, ISSN 0016-5085.

Jones, R. (2001). Nonsteroidal anti-inflammatory drug prescribing: past, present, and future. American Journal of Medicine, Vol.8;110, No.1A (January), pp. 4S-7S, ISSN 0002-9343.

Kato, S.; Aihara, E.; Yoshii, K.; Takeuchi K. (2005). Dual action of prostaglandin E2 on gastric acid secretion through different EP receptor subtypes in the rat. American Journal of Physiology, Vol.89, No.1 (July), pp. G64-G69, ISSN 1522-1539.

Kato, S.; Tanaka, A.; Kunikata, T.; Mizoguchi, H. \& Takeuchi, K. (2000). The roles of nitric oxide and prostaglandins in alterations of ulcerogenic and healing responses in adjuvant- induced arthritic rat stomachs. Alimentary Pharmacology and Therapeutics, Vol.14, No.1 (April), pp. 18-25, ISSN 0269-2813.

Kohda,K.; Tanaka, K.; Aiba, Y.; Yasuda, M.; Miwa, T. \& Koga, Y. (1999). Role of apoptosis induced by Helicobacter pylori infection in the development of duodenal ulcer. Gut, Vol.44, No.4 (April), pp. 456-462, ISSN 0017-5749.

Konturek, S.J.; Brzozowski, T.; Majka, J.; Pytko-Polonczyk, J. \& Stachura, J. (1993). Inhibition of nitric oxide synthase delays healing of chronic gastric ulcers. European Journal of Pharmacology, Vol.2;239, No.1-3 (August), pp. 215-217, ISSN 0014-2999.

Konturek, S.J.; Konturek, P.C. \& Brzozowski, T. (2005). Prostaglandins and ulcer healing. Journal of Physiology and Pharmacology, Vol.56, No.5 (september), pp.5-31, ISSN 0867-5910.

Konturek, S.J.; Piastucki, I.; Brzozowski, T.; Radecki, T.; Dembinska-Kiec, A.; Zmuda, A.; Gryglewski, R. (1981). Role of prostaglandins in the formation of aspirin induced gastric ulcers. Gastroenterology, Vol.80, No.1 (January), pp. 4-9, ISSN 0016-5085.

Kuipers, E.J.; Janssen, M.J. \& Boer, W.A. (2003). Good bugs and bad bugs: indications and therapies for Helicobacter pylori eradication. Current Opinion in Pharmacology, Vol.3, No.5 (October, pp. 480-485, ISSN 1471- 4892. 
La Casa, C.; Villegas, I.; Alarcon de La Lastra, C.; Motilva, V.; Martin Calero, M.J. (2000). Evidence for protective and antioxidant properties of rutin, a natural flavone, against ethanol induced gastric lesions. Journal of Ethnopharmacology, Vol.71, No.1/2 (July), pp. 45-53, ISSN 0378-8741.

Lacy, E.R. \& Ito, R. (1984). Rapid epithelial restitution of the rat gastric mucosa after ethanol injury, Laboratory Investigation, Vol.51, No.5 (November), pp. 573-585, ISSN 0023-6837.

Laine, L.; Curtis, S.P.; Cryer, B.; Kaur, A.; Cannon, C.P. (2007). Assessment of upper gastrointestinal safety of etoricoxib and diclofenac in patients with osteoarthritis and rheumatoid arthritis in the Multinational Etoricoxib and Diclofenac Arthritis Long-term (MEDAL) programme: a randomised comparison. Lancet, Vol.10;369, No.9560 (February), pp. 465-473, ISSN 0140-6736.

Laine, L.; Takeuchi, K. \& Tarnawski, A. (2008). Gastric mucosal defense and cytoprotection: bench to bedside. Gastroenterology, Vol.135, No.1 (July), pp. 41-60, ISSN 0016-5085.

Lanas, A. \& Scheiman, J. (2007). Low-dose aspirin and upper gastrointestinal damage: epidemiology, prevention and treatment. Current Medical Research and Opinion, Vol.23, No.1 (January), pp.163-173, ISSN 0300-7995.

Latarjet A. (1922). Resection des nerfs de I'estomac Technique operatoire. Resultats Clin Bull Acad Med (Paris), Vol.67, pp. 661-691.

Levenstein, S.; Ackerman, S.; Kiecolt-Glaser, J.K.; Dubois, A. (1999). Stress and peptic ulcer disease. Journal of the American Medical Association, Vol.6;281, No.1 (January), pp.10-11, ISSN 00987484.

Levenstein, S.; Kaplan, G.A. \& Smith, M. (1995). Sociodemographic characteristics, life stressors, and peptic ulcer: a prospective study. Journal of Clinical Gastroenterology, Vol.21, No.3 (October), pp. 185-192, ISSN 0192-0790.

Lichtenberger, L.; Graziani, L.A.; Dial, E.J.; Butler, B.D. \& Hills, B.A. (1983). Role of surface active phospholipids in cytoprotection. Science, Vol.18;219, No.4590 (March), pp. 1327-1329, ISSN 0036-8075.

Lichtenberger, L.M. (1999). Gastroduodenal mucosal defense. Current Opinion in Gastroenterology, Vol.15, No.6 (November), pp.463-472, ISSN 0267-1379.

Lindberg, P.; Brändström, A.; Wallmark, B.; Mattsson, H.; Rikner, L. \& Hoffmann, K.J. (1990). Omeprazole: the first proton pump inhibitor. Medicinal Research Reviews, Vol.10, No.1 (January-March), pp. 1-54, ISSN 0198-6325.

Ma, L. \& Wallace, J.L. (2000). Endothelial nitric oxide synthase modulates gastric ulcer healing in rats. American Journal of Physiology: Gastrointestinal and Liver Physiology, Vol.279, No.2 (August), pp.G341-G6, ISSN 0193-1857.

Madara, J.L. (1983). Increases in guinea pig small intestinal transepithelial resistance induced by osmotic loads are accompanied by rapid alterations in absorptive-cell tightjunction structure. Journal of Cell Biology, Vol.97, No.1 (July), pp. 125 - 36, ISSN 0021-9525.

Makola, D.; Peura, D.A. (2007). Crowe SE. Helicobacter pylori infection and related gastrointestinal diseases. Journal of Clinical Gastroenterology, Vol.41, No.6 (July), pp. 548-558, ISSN 0192-0790, 1539-2031.

Marshall, B.J. \& Windsor, H.M. (2005). The relation of Helicobacter pylori to gastric adenocarcinoma and lymphoma: pathophysiology, epidemiology, screening, 
clinical presentation, treatment, and prevention. Medical Clinics of North America., Vol.89, No.2 (March), pp. 313-344, ISSN 00257125.

Matsuda, H.; Pongpiriyadacha, Y.; Morikawa, T.; Kashima, Y.; Nakano, K. \& Yoshikawa, M. (2002) Protective effects of polygodial and related compounds on ethanolinduced gastric mucosal lesions in rats: structural requirements and mode of action. Bioorganic $\mathcal{E}$ Medicinal Chemistry Letters, Vol.11;12, No.3 (February), pp. 477-482, ISSN 0960-894X.

Matysiak-Budnik, T.; Heyman, M.; Mégraud, F. (2003). Review article: rebamipide and the digestive epithelial barrier. Alimentary Pharmacology \& Therapeutics, Vol.18, No.1 (July), pp.55-62, ISSN 0269-2813.

Meyer-Rosberg, K.; Scott, D.R.; Rex, D.; Melchers, K.; Sachs, G. (1996). The effect of environmental $\mathrm{pH}$ on the proton motive force of Helicobacter pylori. Gastroenterology, Vol.111, No.4 (October), pp. 886-900, ISSN 0016-5085.

Moayyedi, P.; Wason, C.; Peacock, R.; Walan, A.; Bardhan, K.; Axon, A.T. \& Dixon, M.F. (2000). Changing patterns of Helicobacter pylori gastritis in long-standing acid suppression. Helicobacter, Vol.5, no.4 (December), pp. 206-214, ISSN 1083-4389.

Moura Rocha, N.F.; Venâncio, E.T.; Moura, B.A.; Gomes Silva, M.I.; Aquino Neto, M.R.; Vasconcelos Rios, E.R.; de Sousa, D.P.; Mendes Vasconcelos, S.M.; de França Fonteles, M.M. \& de Sousa, F.C. (2010). Gastroprotection of (-)-alpha-bisabolol on acute gastric mucosal lesions in mice: the possible involved pharmacological mechanisms. Fundamental and Clinical Pharmacology, Vol.24, No.1 (February), pp. 63-71, ISSN 0767-3981.

Mózsik, G.; Karádi, O.; Király, A.; Debreceni, A.; Figler, M.; Nagy, L.; Pár, A.; Pár, G.; Süto, G. \& Vincze, A. (2001). The key-role of vagal nerve and adrenals in the cytoprotection and general gastric mucosal integrity. Journal of Physiology (Paris), Vol.95, No. 1-6 (January-December), pp.229-237, ISSN 0928-4257.

Murphy, M.S. (1998). Growth factors and the gastrointestinal tract. Nutrition, Vol.14, No.10 (October), pp.771-774, ISSN 0899-9007 .

Nayeb-Hashemi, H. \& Kaunitz, J.D. (2009). Gastroduodenal mucosal defense. Current Opinion in Gastroenterology, Vol.25, No.6 (November), pp. 537-543, ISSN 15317056.

Nusrat, A.; von Eichel-Streiber, C.; Turner, J.R. , Verkade, P.; Madara, J.L.; Parkos, C.A. (2001). Clostridium difficile toxins disrupt epithelial barrier function by altering membrane microdomain localization of tight junction proteins. Infection and Immunity, Vol.69, No.3 (March), pp. 1329 - 1336, ISSN 0019-9567.

Oh, T.Y.; Ahn, G.J.; Choi, S.M.; Ahn, B.O.; Kim, W.B. (2005). Increased susceptibility of ethanol-treated gastric mucosa to naproxen and its inhibition by DA-9601, an Artemisia asiatica extract. World Journal of Gastroenterology, Vol.11, No.47 (December), pp. 7450-7456, ISSN 1007-9327.

Olaleye, S.B.; Adaramoye, O.A.; Erigbali, P.P. \& Adeniyi, O.S. (2007). Lead exposure increases oxidative stress in the gastric mucosa of $\mathrm{HCl}$ /ethanol-exposed rats. World Journal of Gastroenterology, Vol.14;13, No.38 (October), pp. 5121-5126, ISSN 1007-9327.

Oyaka, J. Otaka, M.; Matsuhashi, T.; Jin, M.; Odashima, M.; Komatsu, K.; Wada, I.; Horikawa, Y.; Ohba, R.; Hatakeyama, N.; Itoh, H. \& Watanabe, S. (2006). Overexpression of $70-\mathrm{kDa}$ heat shock protein confers protection against 
monochloramine- induced gastric mucosal cell injury. Life Sciences, Vol.79, No.3 (June), pp. 300-305, ISSN 0730-9384.

Pakodi,F.; Abdel-Salam, O.M.; Debreceni, A. \& Mozsik, G. (2000). Helicobacter pylori. One bacterium and a broad spectrum of human disease! An overview. Journal of Physiology (Paris), Vol.94, No.2 (March-April), pp. 139-152, ISSN 0928-4257.

Parsonnet, J.; Friedman, G.D.; Vandersteen, D.P.; Chang, Y.; Vogelman, J.H.; Orentreich, N.; Sibley, R.K. (1991). Helicobacter pylori infection and the risk of gastric carcinoma. New England Journal of Medicine, Vol.325, No.16 (October), pp. 11271231, ISSN 0028-4793.

Peek, R.M. \& Crabtree, J.E. (2006). Helicobacter infection and gastric neoplasia. Journal of Pathology, Vol.208, No.2 (January), pp. 233-248, ISSN 0022-3417.

Penissi, A. \& Piezzi, R. (1999). Effect of dehydroleucodine on mucus production. A quantitative study. Digestive Diseases and Sciences, Vol.44, No.4 (April), pp. 708712, ISSN 0163-2116.

Peskar, B.M. \& Maricic, N. (1998). Role of prostaglandins in gastro protection. Digestive Diseases and Sciences, Vol. 43, No.9 (September), pp.23S-29S, ISSN 0163-2116.

Peskar, B.M. (2001). Neural aspects of prostaglandin involvement in gastric mucosal defense. Journal of Physiology and Pharmacology, Vol. 52, No.4 (December), pp.555568, ISSN 0867-5910.

Peskar, B.M., Maricic, N.; Gretzera, B.; Schuligoi, R. \& Schmassmann, A. (2001). Role of cyclooxygenase-2 in gastric mucosal defense. Life Sciences, Vol.9;69, No.25-26 (November), pp. 2993-3003, ISSN 0730-9384.

Rehm, J.; Mathers, C.; Popova, S.; Thavorncharoensap, M.; Teerawattananon, Y. \& Patra, J. (2009). Global burden of disease and injury and economic cost attributable to alcohol use and alcohol-use disorders. Lancet. Vol.27;373, No.9682 (June), pp. 2223-2233, ISSN 0140-6736.

Repetto, M.G. \& Llesuy, S.F. (2002). Antioxidant properties of natural compounds used in popular medicine for gastric ulcers. Brazilian Journal of Medical and Biological Research, Vol.35, No.5 (May), pp.523-534, ISSN: 0100-879X.

Richardson, P.; Hawkey, C.J.; \& Stack, W.A. (1998). Proton pump inhibitorspharmacology and rationale for use in gastrointestinal disorders. Drugs, Vol.56, No.3 (September), pp. 307-335, ISSN 0012-6667.

Rosh, J.R. \& Hassall, E. (2006). Therapy with gastric acidity inhibitors increases the risk of acute gastroenteritis and community-acquired pneumonia in children. Journal of Pediatric Gastroenterology \& Nutrition, Vol.43, No.4 (October), pp. 545, ISSN 02772116.

Rostom, A.; Muir, K.; Dube, C.; Jolicoeur, E.; Boucher, M.; Joyce, J.; Tugwell, P. \& Wells, G.W. (2007). Gastrointestinal safety of cyclooxygenase-2 inhibitors: a Cochrane Collaboration Systematic Review. Clinical Gastroenterology and Hepatology, Vol.5, No.7 (Julho), pp. 818-828, ISSN 1542-3565.

Sánchez, M.; Theoduloz, C.; Schmeda-Hirschmann, G.; Razmilic, I.; Yáñez, T. \& Rodríguez, J.A. (2006) Gastroprotective and ulcer-healing activity of oleanolic acid derivatives: in vitro-in vivo relationships. Life Sciences, Vol.79, No.14 (August), pp. 1349-1356, ISSN 0730-9384. 
Santos, F.A. \& Rao, V.S. (2001). 1,8-Cineol, a food-flavouring agent, prevents ethanolinduced gastric injury in rats. Digestive Diseases and Sciences, Vol.46, No.2 (February), pp. 331-337, ISSN 0163-2116.

Schubert, M.L. \& Peura, D.A. (2008). Control of Gastric Acid Secretion in Health and Disease. Gastroenterology, Vol.134, No.7 (June), pp. 1842-1860, ISSN 0016-5085.

Schubert, M.L. (2008). Gastric secretion. Current Opinion in Gastroenterology, Vol.24, No.6 (November), pp. 659-664, ISSN: 0267-1379.

Seno, K.; Joh, T.; Yokoyama, Y. \& Itoh, M. (1995). Role of mucus in gatric mucosal injury induced by local ischemia/reperfusion. Journal of Laboratory and Clinical Medicine, Vol.126, No.13), pp. 287-293, ISSN 0022-2143.

Sigthorsson, G.; Crane, R.; Simon, T.; Hoover, M. ; Quan, H.; Bolognese, J; Bjarnason, I. (2000). COX-2 inhibition with rofecoxib does not increase intestinal permeability in healthy subjects: a double blind crossover study comparing rofecoxib with placebo and indomethacin. Gut, Vol.47, No.4 (October), pp. 527-532, ISSN 00175749 .

Silva, M.I.; Moura, B.A.; Neto, M.R.; Tomé, A.R.; Rocha, N.F.; de Carvalho, A.M.; Macêdo, D.S.; Vasconcelos, S.M.; de Sousa, D.P.; Viana, G.S. \& de Sousa, F.C. (2009a). Gastroprotective activity of isopulegol on experimentally induced gastric lesions in mice: investigation of possible mechanisms of action. Naunyn-Schmiedeberg's Archives of Pharmacology, Vol.380, No.3 (September), pp. 233-245, ISSN 0028-1298.

Silverstein, F.E.; Faich, G.; Goldstein, J.L.; Simon, L.S.; Pincus, T.; Whelton, A.; Makuch, R.; Eisen, G.; Agrawal, N.M. \& Stenson, W.F. (2000). Gastrointestinal toxicity with celecoxib vs nonsteroidal anti-inflammatory drugs for osteoarthritis and rheumatoid arthritis: the CLASS study: a randomized controlled trial. Celecoxib Long-term Arthritis Safety Study. Journal of the American Medical Association, Vol.13;284, No.10 (September), pp. 1247-1255, ISSN 0098-7484.

Singh, G.; Fort, J.G.; Goldstein, J.L.; Levy, R.A.; Hanrahan, P.S.; Bello, A.E.; AndradeOrtega, L.; Wallemark, C.; Agrawal, N.M.; Eisen, G.M.; Stenson, W.F.; Triadafilopoulos, G. (2006). Celecoxib versus naproxen and diclofenac in osteoarthritis patients: SUCCESS-I Study. American Journal of Medicine, Vol.119, No.3 (March), pp. 255-66, ISSN 0002-9343.

Smoot, D.T.; Mobley, H.L.T.; Chippendaele, G.R.; Lewison, J.F. \& Resau, J.H. (1991). Helicobacter pylori urease activity is toxic to human gastric epithelial cells. Infection and Immunity, Vol.59, No.6 (June), pp.1992-1994, ISSN 0019-9567.

Stermer, E. (2002). Alcohol Consumption and the Gastrointestinal Tract. Israel Medical Association Journal., Vol.4, No.3 (March), pp. 200-202, ISSN 1565-1088.

Stroff, T.; Plate, S.; Respondek, M.; Müller, K.M. \& Peskar, B.M. (1995). Protection by gastrin in the rat stomach involves afferent neurons, calcitonin gene-related peptide, and nitric oxide. Gastroenterology, Vol. 109, No.1 (July), pp.89-97, ISSN 0016-5085.

Suerbaum, S. \& Michetti, P. (2002). Helicobacter pylori infection. New England Journal of Medicine, Vol.347, No.15 (October), pp. 1175-1186, ISSN 0028-4793.

Suleyman, H., Akcay, F.; \& Altinkaynak, K. (2002). The effect of nimesulide on the indomethacin- and ethanol-induced gastric ulcer in rats. Pharmacological Research 45, No.2 (February), pp. 155-158, ISSN 1043-6618. 
Suleyman, H.; Demirezer, L.O. \& Kuruuzum-Uz, A. (2004). Effects of Rumex patientia root extract on indomethacine and ethanol induced gastric damage in rats. Pharmazie, Vol.59, No.2 (February), pp. 147-149, ISSN 0031-7144.

Szabo, S.; Trier, J.S. \& Frankel, P.W. (1981). Sulfhydryl compounds may mediate gastric cytoprotection. Science, Vol.9;214, No. 4517 (October), pp. 200-202, ISSN 00368075.

Tanaka, A.; Araki, H.; Komoike, Y.; Hase, S. \& Takeuchi, K. (2001). Inhibition of both COX-1 and COX-2 is required for development of gastric damage in response to nonsteroidal antiinflammatory drugs. Journal of Physiology (Paris), Vol.95, No.1-6 (January-December), p. 21-27, ISSN 0928-4257.

Tanaka, D.; Tsutsumi, S.; Arai, Y.; Hoshino, T.; Suzuki, K.; Takaki, E.; Ito, T.; Takeuchi, K.; Nakai, A. \& Mizushima, T. (2007). Genetic evidence for a protective role of heat shock factor 1 against irritant-induced gastric lesions. Molecular Pharmacology, Vol.71, No.4, pp. 985-993, ISSN 0026-895X.

Tanaka, S.; Tache, Y.; Kaneko, H.; Guth, P.H. \& Kaunitz, J.D. (1997). Central vagal activation increases mucous gel thickness and surface cell intracellular $\mathrm{pH}$ in rat stomach. Gastroenterology, Vol.122, No.2 (February), pp. 409-417, ISSN 0016-5085.

Tarnawski, A.; Hollander, D.; Stachura, J.; Krause, W.J.; Gergely, H. (1985). Prostaglandin protection of the gastric mucosa against alcohol injury-a dynamic time-related process. The role of mucosal proliferative zone. Gastroenterology Vol.88, No.1 (January), pp. 334-359, ISSN 0016-5085.

Tarnawski, A.; Wang, H.; Tomikawa. Talcid triggers induction of heat shock proteins HSP-70 in gastric mucosa: a key to its mucosal protective action? Gastroenterology, Vol.116, pp. A331, ISSN 0016-5085.

Taupin, D. \& Podolsky, D.K. (2003). Trefoil factors initiators of mucosal healing. Nature Reviews Molecular Cell Biology, Vol.4, No.9 (October), 721-732, ISSN 1471-0072.

Terano, A.; Hiraishi, H.; Ota, S.; Shiga, J. \& Sugimoto, T. (1989). Role of superoxide and hydroxyl radicals in rat gastric mucosal injury induced by ethanol. Gastroenterologia Japonica, Vol.24, No.5 (October), pp. 488-493, ISSN 0435-1339.

Trey, G.; Marks, I.N.; Louw, J.A.; Jaskiewicz, K.; Sipponen, P.; Novis, B.H.; Bank, S. \& Tigler-Wybrandi, N.A. (1997). Changes in acid secretion over the years: a 30-year longitudinal study. Journal of Clinical Gastroenterology, Vol.25, No.6 (October), pp. 499-502, ISSN 0192-0790.

Tulassay, Z. \& Herszényi, L. (2010). Gastric mucosal defense and cytoprotection. Best Practice E Research Clinical Gastroenterology, Vol.24, No. 2 (April), pp.99-108, ISSN 1521-6918.

Tuorkey, M.J. \& Abdul-Aziz, K.K. (2011). Gastric Ulcer's Diseases Pathogenesis, Complications and Strategies for Prevention. Webmedcentral, Vol.2, No.3 (March), pp. 2-24, ISSN 2046-1690.

Vane, J.R. \& Botting, R.M. (1995). A better understanding of anti-inflammatory drugs based on isoforms of cyclooxygenase (COX-1 and COX-2). Advances in prostaglandin, thromboxane, and leukotriene research. Vol.23, pp.41-48, ISSN 07328141.

Wallace, J.L. (1992). Prostaglandins, NSAIDs, and cytoprotection. Gastroenterology Clinics of North America, Vol.21, No.3 (September), pp. 631-641, ISSN 0889-8553. 
Wallace, J.L.; McKnight, W.; Reuter, B.K. \& Vergnolle N. (2000). NSAID-induced gastric damage in rats: requirement for inhibition of both cyclooxygenase 1 and 2 . Gastroenterology, Vol.119, No.3 (September), pp. 706-714, ISSN 0016-5085.

Werther, J.L. (2000). The gastric mucosal barrier. Mount Sinai journal of medicine, Vol.67, No.1 (January), pp.41-53, ISSN 0027-2507.

World Health Organization (WHO). (2004). Global Status Report on Alcohol, In: Webcite, 11.11.2010, Available from http://www.who.int/substance_abuse/publications/global_status_report_2004_ overview.pdf.

World Health Organization (WHO). (2008). Is harmful use of alcohol a public health problem?, In: Webcite, 11.11.2010, Available from http://www.who.int/features/qa/66/en/index.html 


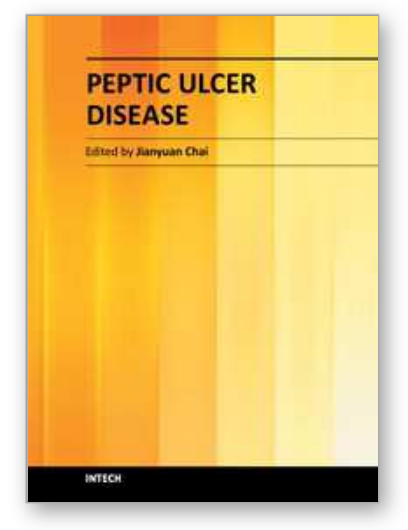

\author{
Peptic Ulcer Disease \\ Edited by Dr. Jianyuan Chai
}

ISBN 978-953-307-976-9

Hard cover, 482 pages

Publisher InTech

Published online 04, November, 2011

Published in print edition November, 2011

Peptic ulcer disease is one of the most common chronic infections in human population. Despite centuries of study, it still troubles a lot of people, especially in the third world countries, and it can lead to other more serious complications such as cancers or even to death sometimes. This book is a snapshot of the current view of peptic ulcer disease. It includes 5 sections and 25 chapters contributed by researchers from 15 countries spread out in Africa, Asia, Europe, North America and South America. It covers the causes of the disease, epidemiology, pathophysiology, molecular-cellular mechanisms, clinical care, and alternative medicine. Each chapter provides a unique view. The book is not only for professionals, but also suitable for regular readers at all levels.

\title{
How to reference
}

In order to correctly reference this scholarly work, feel free to copy and paste the following:

Maria Izabel Gomes Silva and Francisca Cléa Florenço de Sousa (2011). Gastric Ulcer Etiology, Peptic Ulcer Disease, Dr. Jianyuan Chai (Ed.), ISBN: 978-953-307-976-9, InTech, Available from:

http://www.intechopen.com/books/peptic-ulcer-disease/gastric-ulcer-etiology

\section{INTECH}

open science | open minds

\section{InTech Europe}

University Campus STeP Ri Slavka Krautzeka 83/A 51000 Rijeka, Croatia Phone: +385 (51) 770447

Fax: +385 (51) 686166 www.intechopen.com

\section{InTech China}

Unit 405, Office Block, Hotel Equatorial Shanghai No.65, Yan An Road (West), Shanghai, 200040, China 中国上海市延安西路65号上海国际贵都大饭店办公楼 405 单元 Phone: +86-21-62489820

Fax: +86-21-62489821 
(C) 2011 The Author(s). Licensee IntechOpen. This is an open access article distributed under the terms of the Creative Commons Attribution 3.0 License, which permits unrestricted use, distribution, and reproduction in any medium, provided the original work is properly cited. 